\title{
Comparative study on production performances of the Japanese, White, Black and Brown quail at fifth generation
}

\author{
S.Faruque ${ }^{1}$, A.K.F.H. Bhuiyan ${ }^{2}$, M.O.A. Rahman ${ }^{1}$, M.S.K. Sarker ${ }^{1}$ and N.R. Sarker ${ }^{1}$ \\ ${ }^{1}$ Bangladesh Livestock Research Institute, Savar, Dhaka-1341; ${ }^{2}$ Department of Animal Breeding and \\ Genetics, Bangladesh Agricultural University, Mymensingh-2202
}

\begin{abstract}
Four quail genotypes namely Japanese (J), White (W), Black (Bl) and Brown (Br) quail are being maintaining at Bangladesh Livestock Research Institute to develop meat type quail genotype. Studied fifth generation (G5) quails were hatched from 4th generation (G4) parents based on estimated breeding value for 5th week body weight. Standard management practices were followed during study period. Hatching eggs were collected from every single pen of the selected parent quails. A total of 1750 day-old chick comprising of $\mathrm{J}, \mathrm{W}, \mathrm{Br}$ and $\mathrm{Bl}$ were hatched in one batch. Collected data were analyzed in a CRD by General Linear Model (GLM) Univariate Procedure in SPSS Computer Program. Body weight of quails at $3 \mathrm{rd}, 4 \mathrm{th}$, and 6 th week of age were $(\mathrm{p}<0.001)$ influenced by genotype. The 6 th week body weight was $126.51,133.19,130.80$ and $115.40 \mathrm{~g}$, respectively for $\mathrm{J}, \mathrm{W}, \mathrm{Br}$ and $\mathrm{Bl}$ genotypes. Body weight was higher $(\mathrm{p}<0.001)$ in $\mathrm{W}$ and $\mathrm{Br}$ followed by $\mathrm{Bl}$ and $\mathrm{J}$ quail genotypes at different age. The hatchability rate was $(\mathrm{p}<0.001)$ higher in $\mathrm{J}(58.38 \%)$ compared to other three genotypes of $\mathrm{W}(50.30 \%), \mathrm{Br}(47.79 \%)$ and Bl (46.45\%), respectively. Chick mortality during 0 to 5 week age did not varied $(\chi 2=2.19 ; \mathrm{p}>0.05)$ among $\mathrm{Bl}(8.78 \%), \mathrm{J}(6.66 \%), \mathrm{Br}(6.31 \%)$ and $\mathrm{W}(5.36 \%)$ genotypes. Comparing the performances, $\mathrm{W}$ quail was superior for body weight and $\mathrm{Bl}$ quail for egg production.
\end{abstract}

(Key words: Genotype, generation, quail, body weight)

\section{Introduction}

In a developing country, quail is a fangled enterprise of diversification for fulfilling human protein demands (Ali et al., 2012). It is also has been famous in developing countries because of rapid economic return from commercial farming (Minvielle et al., 1999). This bird is used among others for genetic, physiological, biomedical, behavioral, and embryological studies (Huss et al., 2008).

Selection is a great way for genetic up gradation of poultry meat and egg production. Individual selection is particularly essential in selection experiments for body weight in quail. Individual selection is applied based on breeding value for body weight at 5 weeks of age as the selection criterion. The continued selection for 11 generations based on 4th week body weight was increased from 48.9 to $49.7 \%$ in the selected lines of Japanese quail compared to their counterparts reported by Darden and Marks (1988). However, quail breeding work maintaining accurate pedigree records for developing meat type quail genotype is scanty in Bangladesh. Therefore, the present study was undertaken to increase the fifth week body weight of different quail varieties through selective breeding.

\section{Materials and Methods}

This study was conducted with four genotypes of quail namely Japanese (J), White (W), Black (Bl) and Brown (Br)

*Corresponding author: shakila_blri@yahoo.com

Bang. J. Livs. Res. Special Vol. 21-25, 2018: P. 65-68, ISSN 1022-3851 
maintained in Poultry Production Research Division (PPRD), Bangladesh Livestock Research Institute (BLRI), Savar, Dhaka during the year 2014 to 2015. Males and females quail are maintaining in cages for single pair mating through close breeding system for producing each generation. Pedigree records are kept. Each bird was marked by using commercially available leg bands. For producing 5th generation (G5), parent quails of each genotype were selected from the 4th generation (G4) on the basis of breeding value according to their 5th week's body weight. Hatching eggs were collected from every single pen of the selected parent quails. The chicks were housed and reared in brooder house in litter system up to 5 weeks of age. Then birds were shifted to individual cages in laying house and reared up to 30 weeks of age. All birds were fed on quail starter diet $(27 \%$ crude protein and $3200 \mathrm{kcal}$ $\mathrm{ME} / \mathrm{kg}$ ) up to first 5 weeks of age. Then laying diet containing $24 \%$ crude protein and $3000 \mathrm{kcal} \mathrm{ME} / \mathrm{kg}$ were provided to the birds till to the end of study. Data on egg weight, hatchability, body weight of chick at first day, 2nd weeks, 4th weeks, 5th weeks and 6th weeks of age, feed intake, mortality, egg production were recorded for the study of their productive and reproductive performances.

\section{Statistical Model}

The following general linear statistical model was used to analyze the different parameters:

Yik $=\mu+$ gi + eik,

Where, Yik is the dependent variable of the experiment;

$\mu$ is the overall mean;

gi is the effect of ith genotype (i=1-4);

eik is the error term specific to each record.

\section{Statistical Analysis}

All Collected data were analyzed by General Linear Model (GLM) Univariate Procedure in SPSS Computer Program (SPSS, 1998; version 11.5). The data were arranged for a Completely Randomized Design (CRD) for the Analysis of Variance (ANOVA). Least significant differences (LSD) were used for mean comparison.

\section{Results and Discussion}

Body weights of four genotypes of quail at $3 \mathrm{rd}$, 4th and 6th weeks of age are shown in Table 1 . Body weight of quails at $3 \mathrm{rd}$, 4th and 6 th of age were influenced $(\mathrm{p}<0.001)$ by genotypes. The 6 th week body weight was $126.51 \pm 1.23,133.19 \pm 0.99,130.80 \pm 1.11$ and $115.40 \pm 1.21 \mathrm{~g}$, respectively for Japanese, White, Brown and Black genotypes.

Table 1. Least squares means (LSM) and standard error of means (SEM) of different weight traits as affected by genotype

\begin{tabular}{cccc}
\hline Genotype & $3^{\text {rd }}$ wk body weight & $4^{\text {th }}$ wk body weight & $6^{\text {th }}$ wk body weight \\
\hline Japanese & $66.82^{\mathrm{c}} \pm 0.63(756)$ & $91.09^{\mathrm{b}} \pm 0.80(742)$ & $126.51^{\mathrm{b}} \pm 1.23(728)$ \\
White & $77.03^{\mathrm{a}} \pm 0.69(400)$ & $103.01^{\mathrm{a}} \pm 0.55(394)$ & $133.19^{\mathrm{a}} \pm 0.99(388)$ \\
Brown & $72.67^{\mathrm{b}} \pm 0.65(398)$ & $90.90^{\mathrm{b}} \pm 0.84(391)$ & $130.80^{\mathrm{a}} \pm 1.11(386)$ \\
Black & $66.21^{\mathrm{c}} \pm 0.59(141)$ & $87.45^{\mathrm{c}} \pm 0.74(138)$ & $115.40^{\mathrm{c}} \pm 1.21(135)$ \\
LS & $\mathrm{p}<0.001$ & $\mathrm{p}<0.001$ & $\mathrm{p}<0.001$ \\
\hline
\end{tabular}

Figure in the parenthesis indicate the number of observations. Least squares means without a common superscript along the column differed significantly $((\mathrm{p}<0.05)$. LS $=$ Level of Significance 
Significantly higher body weight was found in White followed by Brown, Japanese and Black quail genotypes at different periods of age. These values are agreed with the results presented by Rahman et al. (2010) and Islam et al. (2011). They also reported that body weights at different ages were influenced by quail genotypes.

The production and reproduction performance of four studied quail genotypes are presented in Table 2. Hatchability is one of the important reproductive traits which is influenced significantly by the genotypic effect. The hatchability of incubated eggs was $58.38 \%$, $47.79 \%, 46.45 \%$ and $50.30 \%$ for Japanese, Brown, Black and White quail, respectively. difference was observed among four genotypes. Significantly more production of eggs was obtained in Black (69.15\%) followed by Japanese, White and Brown; respectively. The present findings were mostly supported by Rahman et al. (2010) and Homna et al. (1985) who opined that egg production was significantly influenced by different types of quail genotype.

The mortality percentage during $0-5$ weeks of age were significantly $(\mathrm{p}<0.01)$ influenced by the genotype (Table 3). The highest value was observed (8.78\%) in Black genotype followed by Japanese (6.66\%), Brown $(6.31 \%)$ and White $(5.36 \%)$, respectively.

Table 2. Productive and reproductive performance of four quail genotypes

\begin{tabular}{lllllc}
\hline \multicolumn{1}{c}{ Parameter } & \multicolumn{3}{c}{ Quail varieties (Mean \pm SE) } & \multicolumn{1}{c}{$\begin{array}{l}\text { Level of } \\
\text { Significance }\end{array}$} \\
\cline { 2 - 5 } & Japanese & Brown & Black & White & \\
\hline $\begin{array}{l}\text { Hatchability on } \\
\text { setting eggs (\%) }\end{array}$ & $58.38^{\mathrm{a}} \pm 3.21$ & $47.79^{\mathrm{b}} \pm 2.56$ & $46.45^{\mathrm{b}} \pm 3.54$ & $50.30^{\mathrm{b}} \pm 2.67$ & $\mathrm{p}<0.001$ \\
Feed Intake(g/b/d) & $11.32 \pm 0.84$ & $10.68 \pm 0.84$ & $10.21 \pm 0.84$ & $10.66 \pm 0.84$ & NS \\
HDEP (\%) & $57.38^{\mathrm{b}} \pm 3.5$ & $48.14^{\mathrm{b}} \pm 3.3$ & $69.15^{\mathrm{a}} \pm 3.4$ & $54.80^{\mathrm{b}} \pm 3.5$ & $\mathrm{p}<0.001$ \\
\hline
\end{tabular}

HDEP - Hen day egg production, Least squares means without a common superscript along the row differed significantly $((\mathrm{p}<0.05)$

The highest hatchability was found in Japanese genotype, although no significant differences were found among Brown, White and Black genotypes. No significant difference was found in feed intake among the four genotypes. Hen-day egg production (HDEP) was $57.38 \%, 48.14 \%, 69.15 \%$ and $54.80 \%$, respectively, for Japanese, Brown, Black, white genotypes of quail and significant

Table 3. Effect of genotype on chick mortality (\%) during 0-5 weeks of age

\begin{tabular}{|c|c|c|c|c|c|c|}
\hline \multirow[t]{2}{*}{ Parameter } & \multicolumn{4}{|c|}{ Genotype } & \multirow{2}{*}{$\begin{array}{c}x^{2} \\
(d f=3)\end{array}$} & \multirow[t]{2}{*}{ P-value } \\
\hline & Japanese & White & Black & Brown & & \\
\hline $\begin{array}{c}\text { Mortality } \\
(\%)\end{array}$ & 6.66 & 5.36 & 8.78 & 6.31 & 2.19 & $\mathrm{p}>0.05$ \\
\hline
\end{tabular}


Table 4. Selection differential, selection intensity for 5 weeks body weight $(\mathrm{g})$ in fifth generation $\left(\mathrm{G}_{5}\right)$ of quail

\begin{tabular}{|c|c|c|c|c|c|c|c|}
\hline \multirow{2}{*}{ Genotype } & \multirow{2}{*}{ Sex } & \multicolumn{2}{|c|}{ Before selection } & \multicolumn{2}{|c|}{ After selection } & \multirow{2}{*}{$\begin{array}{l}\text { Selection } \\
\text { Differential } \\
\quad(\mathrm{S})(\mathrm{g})\end{array}$} & \multirow{2}{*}{$\begin{array}{l}\text { Selection } \\
\text { Intensity (i) }\end{array}$} \\
\hline & & No. & Avg bwt & No. & $\begin{array}{l}\text { Avg } \\
\text { bwt }\end{array}$ & & \\
\hline \multirow[t]{2}{*}{ Japanese } & M & 328 & 103.2 & 150 & 109.3 & 6.1 & 0.83 \\
\hline & $\mathrm{F}$ & 352 & 109.9 & 150 & 118.6 & 8.7 & 0.93 \\
\hline \multirow[t]{2}{*}{ White } & M & 171 & 119.4 & 120 & 123.7 & 4.3 & 0.47 \\
\hline & $\mathrm{F}$ & 208 & 125.4 & 120 & 133.0 & 7.6 & 0.67 \\
\hline \multirow[t]{2}{*}{ Brown } & M & 185 & 110.8 & 120 & 115.4 & 4.6 & 0.57 \\
\hline & $\mathrm{F}$ & 186 & 111.6 & 120 & 118.1 & 6.5 & 0.58 \\
\hline \multirow[t]{2}{*}{ Black } & M & 68 & 99.9 & 30 & 107.2 & 7.3 & 0.92 \\
\hline & $\mathrm{F}$ & 62 & 103.2 & 30 & 111.0 & 7.8 & 0.82 \\
\hline
\end{tabular}

Avg, Average; bwt, Body Weight

\section{Conclusion}

Comparing the performances, white quail was superior for body weight and black quail for egg production.

\section{Acknowledgement}

The authors are very grateful to Director General, Bangladesh Livestock Research Institute and Head, Poultry Production Research Division, Bangladesh Livestock Research Institute for providing necessary facilities to conduct the research.

\section{References}

Ali, M.A., Hmar, L., Devi, L.I.M.P., Lallianchhunga, M. C. and Tolenkhomba, T. C. 2012. Effect of age on the haematological and biochemical profile of Japanese quails, (Coturnix coturnix japonica). International Multidisciplinary Res. J. 2:32-35

Darden, J.R. and Marks, H.L. 1988. Diverge selection for growth in Japanese quail under split and complete nutritional environments: 2 . Water and feed intake patterns and abdominal fat and carcass lipid characteristics. Poultry
Science, 67: 1111-1122

Homna, K., Oki, H. and Watanabe, G. 1985. A plumage color mutation in Japanese quail associated with female specific sterility due to oviduct dysfunction. Japanese J. Anim. Reprod. 31: 84-89

Huss, D., Poynter, G. and Lansford, R. 2008. Japanese quail (Cotur-nix japonica) as a laboratory animal model. Lab. Anim. (NY) 37: 513-519

Islam, M.N., Rahman, M.S. and Khatun, H. 2011. Improvement of different color mutations of quails for meat production. Proceedings of the Annual Research Review Workshop-2011, BLRI, Savar, Dhaka, Bangladesh. pp: 74-77

Minvielle, F., Hirigoyen, E. and Boulay, M. 1999. Associated effects of the roux plumage color mutation on growth, carcass traits, egg production, and reproduction of Japanese quail. Poultry Science, 78 : 1479-1484

Rahman, M.S., Rasul, K.M.G. and Islam, M.N. 2010. Comparison of the productive and reproductive performance of different color mutants of Japanese quails (coturnix japonica). Proceedings of the Annual Research Review Workshop-2010, BLRI, Savar, Dhaka, Bangladesh. pp: 50-56 